\title{
KAJIAN PERSYARATAN TEKNIS LABORATORIUM PENGUJIAN DI INDUSTRI SUSU TERHADAP PRODUK INFANT FORMULA SESUAI ISO 17025:2017
}

\author{
Review on Technical Requirements of Testing Laboratory in The Dairy Industry for \\ Infant Formula According to ISO 17025: 2017
}

\author{
Dwining Putri Elfriede, Harsi D. Kusumaningrum, Hanifah Nuryani Lioe
}

\author{
Departemen IImu dan Teknologi Pangan, Fakultas Teknologi Pertanian, Institut Pertanian Bogor, Kampus IPB \\ Dramaga, PO Box 22016002 Bogor, Jawa Barat, Indonesia \\ e-mail: harsikusumaningrum@apps.ipb.ac.id
}

Diterima: 20 Oktober 2018, Direvisi: 28 November 2018, Disetujui: 30 November 2018

\begin{abstract}
Abstrak
Susu infant formula adalah susu yang secara khusus diformulasikan sebagai pengganti ASI untuk bayi sampai berusia 6 (enam) bulan. Mutu dan keamanan pangan merupakan salah satu parameter penting dalam memproduksi pangan, termasuk susu infant formula. Peran laboratorium menjadi sangat penting untuk mengukur dan memastikan terjaminnya mutu dan keamanan pangan melalui ISO 17025. Hasil pengukuran yang dicantumkan pada label kemasan pangan dapat mendukung perlindungan bayi. Dalam hal ini label menjadi sarana komunikasi produsen kepada konsumen. Penelitian ini dilakukan di laboratorium pada suatu industri susu infant formula yang belum terakreditasi ISO 17025. Tujuan penelitian adalah menganalisis pemenuhan regulasi mutu, keamanan dan kemasan pada industri serta memberikan rekomendasi pada laboratorium tersebut sesuai persyaratan teknis ISO 17025. Standar regulasi yang dianalisis yaitu regulasi Indonesia, regulasi internasional menurut Codex, Malaysia dan Filipina. Hasil penelitian menunjukkan pemenuhan persyaratan parameter susu infant formula terkait mutu, keamanan dan kemasan sudah melebihi 50\%. Penilaian pemenuhan persyaratan terkait mutu, kemanan mikrobiologi dan kimia serta kemasan secara berurutan adalah $100 \%(33 / 33), 50 \%(3 / 6)$, $71.42 \%$ (5/7) dan $91.67 \%$ (11/12). Data kuantitatif hasil penilaian menunjukkan bahwa laboratorium pengujian susu infant formula sudah mengimplementasikan 93\% pemenuhan persyaratan teknis ISO 17025 . Pemenuhan persyaratan teknis terhadap masing-masing sub klausul keterlusuran metrologis, pemilihan, verifikasi dan validasi metode, pengambilan sampel dan penanganan barang yang diuji sudah mencapai $100 \%$, namun untuk subklausul peralatan hanya mencapai $78 \%$. Rekomendasi dalam pemenuhan kesenjangan persyaratan ISO 17025 mencakup kalibrasi peralatan, penulisan logbook, jadwal pengecekan antara, rekaman peralatan serta perencanaan dan pelaksanaan validasi/verifikasi.
\end{abstract}

Kata kunci: analisis kesenjangan, infant formula, ISO 17025, laboratorium pengujian, persyaratan teknis

\begin{abstract}
Infant formula is a milk product that specifically formulated as a substitute for breast milk for babies up to 6 months old. The laboratory has a very important role to measure and ensure the quality and safety of food through implementation of ISO 17025. The labelling becomes a means of communication between producers and consumers. This research was conducted in a laboratory of infant formula industry that has not been accredited by ISO 17025. The research objectives are to analyze the fulfillment of quality, safety and labeling regulations in the industry and provide recommendations according to technical requirements ISO 17025. Regulatory standards analyzed are Indonesian regulations, international standars according to Codex, as well as Malaysia and the Philippines regulations. Assessment of requirements related to quality, microbiological and chemical safety and labeling is 100\% (33/33), 50\% (3/6), 71.42\% (5/7) and 91.67\% (11/12), respectively. Quantitative data from assessment results indicate that the testing laboratory has implemented $93 \%$ of technical requirements ISO 17025. Fulfillment of technical requirements for subclause of equipment was $78 \%$, while for metrological flexibility, selection, verification and method validation, sampling and handling of items tested were $100 \%$. Recommendations for meeting ISO 17025 requirements gaps are equipment calibration, logbook writing, intermediate checking schedules, equipment recording, and validation/verification planning and implementation.
\end{abstract}

Keyword: gap analysis, infant formula, ISO 17025, testing laboratory, technical requirements 


\section{PENDAHULUAN}

Susu infant formula adalah produk susu yang secara khusus diformulasikan sebagai pengganti ASI untuk bayi sampai berusia 6 (enam) bulan (BPOM 2009). Mutu dan keamanan pangan merupakan salah satu parameter penting dalam memproduksi pangan, termasuk susu infant formula (Misgiyarta dan Bintang 2011). Menurut Organisasi Kesehatan Dunia (WHO) dan Badan PBB yang menangani anak (UNICEF), hanya $61 \%$ ibu yang menyusui bayinya selama empat bulan dan $35 \%$ yang menyusui hingga enam bulan, sehingga susu merupakan asupan utama bagi bayi setelah menyusui (Tampubolon et al. 2015). Mutu dan keamanan kandungan zat gizi infant formula harus terbukti secara ilmiah dapat mendukung pertumbuhan dan perkembangan bayi. Label kemasan pangan yang sesuai standar juga dapat mendukung dalam melindungi bayi sebagai sarana komunikasi produsen kepada konsumen mengenai pilihan berdasarkan informasi.

Peran laboratorium sebagai suatu instrumen yang mengendalikan dan mengukur kualitas mutu dan keamanan produk yang berdasarkan regulasi atau standar yang berlaku. Berdasarkan penelitian Anggraini (2009), persebaran data (standar deviasi) karakteristik mutu susu infant formula di pasar Indonesia yang paling tinggi adalah karbohidrat dan vitamin B3. Persebaran data (standar deviasi) karakteristik keamanan susu infant formula di pasar Indonesia yang paling tinggi adalah angka lempeng total dan arsen.

Salah satu cara yang paling baik untuk menjamin mutu dan keamanan pangan, keakuratan data hasil uji serta meningkatkan percaya diri para praktisi laboratorium melalui program akreditasi. Akreditasi laboratorium melibatkan penilaian eksternal untuk mengukur kinerja dan kualitas hasil analisis laboratorium sesuai dengan standar (Rose dan Johnson 2017). Didalam mencapai keseragaman hasil analisis antar laboratorium dibutuhkan suatu standar yang bersifat internasional yang mencakup sistem mutu dan teknis yang baik, salah satunya adalah standar ISO/IEC 17025:2017 General Requirements for the Competence of Testing and Calibration Laborataries.

Indonesia telah mengadopsi ISO 17025 melalui Badan Standardisasi Nasional (BSN). BSN merupakan lembaga yang ditunjuk oleh pemerintah untuk menyusun, mengadopsi, merevisi dan mengesahkan Standar Nasional Indonesia (SNI). Lembaga yang ditunjuk pemerintah untuk melakukan akreditasi terhadap laboratorium dan badan sertifikasi adalah Komite Akreditasi Nasional (KAN). Akreditasi yang dikeluarkan KAN sudah diakui oleh negaranegara kawasan Asia Pasifik karena sudah mempunyai perjanjian saling pengakuan (Mutual Recognition Agreement).

Proses mendapat akreditasi ISO 17025 menurut Khodabocus dan Balgobin (2011) dimulai dari pemahaman menyeluruh dari standar ISO 17025, kemudian melakukan gap analysis untuk menentukan tahap kepatuhan laboratorium dengan persyaratan. Hasil gap analysis merupakan dasar untuk rencana mutu dan stategi implementasi (Zapata et al. 2007). Persyaratan teknis merupakan salah satu persyaratan utama yang harus terpenuhi dalam pemenuhan standar ISO 17025.

Pemenuhan persyaratan teknis akan menjadi tolak ukur untuk melakukan penilaian dari pihak independen untuk proses akreditasi. Berbagai faktor dapat menentukan kebenaran dan kehandalan pengujian yang dilakukan oleh laboratorium. Faktor tersebut meliputi faktor manusia, kondisi akomodasi dan lingkungan, metode pengujian dan validasi metode, peralatan, keterlusuran pengukuran, pengambilan contoh, serta penanganan barang yang diuji (SNI 2008). Faktor yang harus diperhatikan dalam pemenuhan persyaratan teknis adalah metode validasi, manajemen peralatan, kontrol kualitas dan ketelusuran (Zapata et al. 2007). Subklausul yang terkait dengan persyaratan teknis tersebut dalam ISO (2017) adalah peralatan, ketelusuran metrologi, pemilihan, verifikasi dan validasi metode uji, pengambilan sampel, penanganan benda uji.

PT. XYZ sebagai lokasi studi kasus merupakan industri susu infant formula yang telah mendistribusikan produknya ke pasar nasional maupun internasional. PT XYZ ingin menerapkan persyaratan dasar khususnya persyaratan parameter teknis sesuai ISO 17025 pada produk yang akan dikaji dalam penelitian ini. Pemenuhan persyaratan ini dapat menjamin komitmen semua personel dengan kebutuhan pelanggan yang diakui dan memenuhi regulasi nasional maupun internasional.

Tujuan utama penelitian ini adalah mengidentifikasi regulasi terkait susu infant formula dalam hal mutu, keamanan dan label kemasan untuk mengetahui standar peraturan yang berlaku dan perkembangan teknologi terutama dalam metode uji dan persyaratan mutu secara nasional dan internasional. Selain itu untuk menganalisis kesenjangan kondisi dan kemampuan laboratorium pengujian terhadap pemenuhan persyaratan teknis parameter mutu (karbohidrat dan Vitamin B3), keamanan (angka lempeng total dan arsen) berdasarkan ISO 17025. Kemudian menyusun rekomendasi terkait hasil analisis kesenjangan untuk menjelaskan dan memberikan prioritas dalam tindakan yang 
harus diambil. Rekomendasi membentuk suatu landasan untuk melakukan evaluasi berkala dan tindak lanjut untuk perusahaan sejenis lainnya.

\section{TINJAUAN PUSTAKA}

\subsection{Standar Regulasi Susu Infant Formula}

Syarat mutu bahan utama susu infant formula yang berlaku di Indonesia terbagi atas enam kandungan yaitu protein, total lemak, karbohidrat, vitamin, mineral dan komponen lain. Masingmasing kandungan terbagi menjadi beberapa jenis kandungan yang memiliki batas minimum, maksimum dan acuan batas atas (ABA). ABA digunakan untuk zat gizi yang tidak mempunyai informasi cukup tentang kajian risiko berbasis ilmiah. Kandungan zat gizi infant formula biasanya tidak melebihi ABA kecuali jika tidak dapat dihindari sehubungan dengan keragaman kandungan formula atau karena alasan teknologi.

Persyaratan mikroba yang diatur dalam BPOM (2016) ditentukan untuk mengetahui kondisi produk akhir dan sistem higienis dan sanitasi pada proses produksi. Indikator yang digunakan untuk mengetahui hal tersebut adalah mikroba patogen dan mikroba indikator proses higienis (Hervert dkk 2016). Persyaratan batas cemaran mikroba pada susu infant formula yang berlaku di Indonesia sebanyak empat jenis yaitu ALT, Enterobacteriaceae, Enterobacter sakazakii (Oonaka dkk 2010), Salmonella (Angulo dkk 2008). Persyaratan batas cemaran kimia pada susu infant formula yang berlaku di Indonesia yang diatur dalam BPOM (2017) sebanyak lima jenis yaitu Arsen, Timbal, Merkuri, Kadmium dan Timah.

Label kemasan merupakan salah satu komunikasi sederhana yang dapat memberikan manfaat untuk mengendalikan makanan dan membuat konsumen bertanggung jawab terhadap makanan yang dipilih (Viola dkk 2016). Produsen dan/atau distributor susu infant formula mencantumkan label pada setiap kemasan susu. Persyaratan label yang diatur dalam Menkes (2013), memuat nama produk, daftar bahan yang digunakan, berat bersih atau isi bersih, informasi nilai gizi, tanggal kadaluwarsa dan petunjuk penyimpanan, keterangan tentang peruntukan, cara penggunaan, nama dan alamat pihak yang memproduksi atau memasukkan ke Indonesia dan keterangan lain yang perlu diketahui.

\subsection{Strategi Implementasi ISO 17025}

Menurut Firdaus (2015), ada 3 hal yang perlu diperhatikan dalam penerapan sistem manajemen mutu laboratorium. Pertama, komitmen dari manajemen puncak yang menjadi kunci sukses seluruh program implementasi yang tercermin dalam dukungannya terhadap penyelenggaraan penjaminan mutu laboratorium mulai dari perancangan sampai dengan pemeliharaannya. Dukungan manajemen puncak adalah faktor kunci yang mempengauhi kesuksesan implementasi suatu projek.Kedua, desain organisasi sistem mutu yang baik dengan tersedianya manajemen puncak, manajer mutu, manajer teknis dan manajer administrasi. Menurut Ulfiati (2016), sistem manajemen mutu dalam suatu organisasi adalah jaminan tentang kemampuannya menyediakan secara konsisten produk atau jasa yang memenuhi persyaratan. Ketiga, dokumentasi sistem mutu meliputi panduan mutu, prosedur instruksi kerja dan formulir yang perlu melibatkan bagian atau personel yang terkait dengan proses pekerjaan.

Seluruh personel dalam organisasi sistem mutu laboratorium perlu memahami secara menyeluruh mengenai regulasi produk dan persyaratan ISO 17025 (Dina dan Wastra 2013). Penetapan perbaikan ataupun perubahan sistem laboratorium didasarkan pada tahap gap analisis untuk memeriksa kesenjangan antara kondisi yang ada dengan persyaratan ISO 17025. Menurut Grochau dkk (2010), aspek yang perlu dicek untuk melakukan studi kesenjangan meliputi (1) status peralatan dan kalibrasi yang tepat; (2) pengetahuan dan keterampilan staf; (3) penggunaan metode analisis yang jelas dan divalidasi; dan (4) kecukupan peralatan.

\section{METODE PENELITIAN}

\subsection{Identifikasi regulasi terkait susu infant formula \\ Identifikasi regulasi terkait susu infant} formula mencakup regulasi yang berlaku secara nasional di Indonesia, internasional menurut Codex dan negara tujuan ekspor Indonesia yaitu Malaysia dan Filipina. Metode yang digunakan adalah studi literatur. Regulasi dikelompokkan berdasarkan mutu, keamanan pangan dan label kemasan. Hasil pengelompokkan ini akan menjadi acuan untuk menganalisis kondisi laboratorium pengujian dan memberikan rekomendasi perbaikan dengan mengacu regulasi yang berlaku.

\subsection{Analisis kesenjangan pemenuhan} persyaratan teknis ISO 17025

Tahapan ini mempelajari dokumen terkait implementasi ISO 17025 yang meliputi panduan mutu, prosedur, instruksi kerja, catatan mutu dan dokumen pendukung lainnya. Penelitian dilakukan di laboratorium pengujian PT $X Y Z$, kabupaten Karawang, Jawa Barat selama 4 (empat) bulan dari bulan Februari 2018 sampai dengan bulan Juni 2018.

Kondisi dan kemampuan laboratorium ini akan digunakan untuk menganalisis kesenjangan persyaratan parameter uji sesuai standar ISO 17025 berdasarkan observasi lapang. Analisis 
kesenjangan dilakukan untuk pemenuhan persyaratan analisis yang menyangkut parameter mutu (analisis karbohidrat dan Vitamin $\mathrm{B}_{3}$ ), keamanan (analisis angka lempeng total dan total arsen). Persyaratan parameter uji pada butir klausul ISO 17025 yang akan dikaji meliputi peralatan, kemampuan telusur, verifikasi dan validasi metode, pengambilan sampel dan penanganan pengujian yang dijelaskan secara terperinci pada lampiran.

Persyaratan parameter uji mencakup pemenuhan karakteristik mutu dan kemananan susu infant formula berdasarkan metode konvensional dan metode instrumen sesuai dengan standar nasional maupun internasional. Penilaian kesesuaian kriteria analisis kesenjangan terhadap pemenuhan persyaratan regulasi dapat menggunakan skala $0,1,2,3$ seperti tercantum pada Tabel 1.

Tabel 1 Skala Kriteria Analisis Kesenjangan.

\begin{tabular}{|c|c|c|}
\hline Deskripsi & Kesesuaian & Skala \\
\hline $\begin{array}{lr}\text { Persyaratan } & \text { kriteria } \\
\text { terpenuhi dan dilakukan } \\
\text { secara konsisten }\end{array}$ & $>80 \%$ & 3 \\
\hline $\begin{array}{lr}\text { Persyaratan } & \text { kriteria } \\
\text { terpenuhi namun tidak } \\
\text { dilakukan secara konsisten }\end{array}$ & $70-80 \%$ & 2 \\
\hline $\begin{array}{l}\text { Persyaratan } \\
\text { terpenuhi dalam bateria } \\
\text { memadai pada saat audit } \\
\text { namun tidak memberikan } \\
\text { pengaruh langsung terhadap } \\
\text { keamanan pangan }\end{array}$ & $50-70 \%$ & 1 \\
\hline $\begin{array}{l}\text { Tidak ada persyaratan } \\
\text { kriteria yang terpenuhi saat } \\
\text { audit }\end{array}$ & $<50 \%$ & 0 \\
\hline
\end{tabular}

Menurut Zamrudi et al (2014), metode kuantifikasi kesesuaian persyaratan dihitung berdasarkan jumlah nilai pemenuhan subkalusul dibagi nilai penuh subklausul, dikali 100

\section{\% Pemenuhan Persyaratan

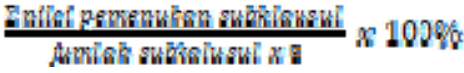

Keterangan :

Angka 3 pada pembagi merupakan konstanta apabila seluruh persyaratan subklausul sudah diimplementasi (Zamrudi et al 2014).

\section{HASIL DAN PEMBAHASAN}

\subsection{Regulasi Terkait Mutu Susu Infant Formula}

Perbandingan keempat regulasi yaitu regulasi Indonesia, Internasional, Malaysia dan Filipina terkait mutu susu Infant Formula dapat dilihat pada Tabel 2. Pemilihan regulasi Negara Malaysia dan Filipina dipilih sebagai negara perwakilan tujuan ekspor susu infant formula produksi Indonesia. Regulasi Filipina menggunakan batas rekomendasi dikarenakan negara Filipina belum membuat standar khusus terkait mutu. Tabel 2 menunjukkan semua spesifikasi produk parameter terkait mutu sudah memenuhi syarat mandatori regulasi. Spesifikasi parameter susu terkait mutu sudah memenuhi syarat mandatori regulasi sebesar 100\% (33/33).

Nilai spesifikasi produk untuk parameter karbohidrat masih sesuai standar sebesar 11 $\mathrm{g} / 100$ kkal karena berada dibatas minimum dan maksimum. Regulasi Indonesia dan Internasional mensyaratkan batas karbohidrat pada susu infant formula tidak boleh kurang dari 9 dan tidak boleh lebih dari $14 \mathrm{~g} / 100$ kkal produk siap konsumsi. Spesifikasi produk ini sesuai dengan kisaran nilai kadar karbohidrat susu infant formula dipasar Indonesia yaitu 10 - $11.2 \mathrm{~g} / 100$ kkal produk siap konsumsi (Anggraini 2009). Sebesar 73\% susu infant formula dilndonesia memiliki sebaran nilai karbohidrat kurang dari nilai tengah batasan standar yaitu 11.3-12.5 g/100 kkal. Karbohidrat berfungsi sebagai sumber energi yang penting bagi bayi. Nilai minimum yang dipersyaratkan adalah jumlah yang diperlukan untuk memenuhi $56 \%$ kebutuhan energi bayi.

Nilai spesifikasi produk untuk parameter vitamin B3 (niasin) masih sesuai standar sebesar $820 \mu \mathrm{g} / 100$ kkal karena berada diatas nilai minimum. Berdasarkan regulasi Indonesia, Internasional, Malaysia dan Filipina mensyaratkan batas niasin pada susu infant formula tidak boleh kurang dari $223 \mu \mathrm{g} / 100 \mathrm{kkal}$ produk siap konsumsi. Spesifikasi produk ini sesuai dengan kisaran nilai kadar niasin susu infant formula dipasar Indonesia yaitu 728 - 970 $\mu \mathrm{g} / 100 \mathrm{kkal}$ produk siap konsumsi (Anggraini 2009). Sebesar 19\% susu infant formula dilndonesia memiliki sebaran nilai niasin lebih dari nilai tengah batasan standar yaitu 243 - 485 $\mu \mathrm{g} / 100$ kkal. Fungsi utama niasin adalah sebagai koenzim NAD dan NAD+.

\subsection{Regulasi terkait keamanan susu infant formula}

Regulasi terkait keamanan mikrobiologi susu Infant Formula dapat dilihat pada Tabel 3. Regulasi Indonesia, Internasional, Filipina dan spesifikasi produk sudah menetapkan batas maksimum mikro ( $\mathrm{M}$ dan atau $\mathrm{m}$ ) dan rencana sampling yang meliputi jumlah contoh (n) dan jumlah contoh yang diterima (c). Malaysia hanya menetapkan satu batas maksimum dengan unit analisis dan tidak menetapkan rencana sampling. Pemilihan rencana sampling dapat dilakukan dengan mempertimbangkan kasus berdasarkan keketatan rencana sampling. Menurut Martoyo Hariyadi dan Rahayu (2014), semakin tinggi keyakinan yang diinginkan dan patogen yang ditetapkan semakin berbahaya, maka semakin 
banyak jumlah $\mathrm{n}$ dan unit analisis tetapi nilai c mikroba pada spesifikasi produk yang belum semakin kecil Spesifikasi parameter susu terkait memenuhi syarat mandatori adalah parameter keamanan mikrobiologi sudah memenuhi syarat Salmonella, Coliform dan E. coli. mandatori regulasi sebesar $50 \%(3 / 6)$. Jenis

Tabel 2 Perbandingan regulasi terkait mutu susu infant formula.

\begin{tabular}{|c|c|c|c|c|c|c|c|c|c|}
\hline \multirow{2}{*}{ Parameter } & \multirow{2}{*}{ Satuan } & \multicolumn{2}{|c|}{$\begin{array}{l}\text { Regulasi } \\
\text { Indonesia }\end{array}$} & \multicolumn{2}{|c|}{$\begin{array}{c}\text { Regulasi } \\
\text { Internasional }^{b}\end{array}$} & \multicolumn{2}{|c|}{$\begin{array}{l}\text { Regulasi } \\
\text { Malaysia }^{c}\end{array}$} & \multirow{2}{*}{$\begin{array}{c}\text { Regulasi } \\
\text { Filipinad }^{\text {d }} \\
\text { Rekomen- } \\
\text { dasi }\end{array}$} & \multirow{2}{*}{$\begin{array}{l}\text { Spesifikas } \\
\text { Produk }\end{array}$} \\
\hline & & $\min$ & mak & $\min$ & mak & $\min$ & mak & & \\
\hline $\begin{array}{l}\text { Protein } \\
\text { Lipida }\end{array}$ & g/100 kkal & 1.8 & 3.0 & 1.8 & 3 & 1.8 & 4.5 & 1.3 & 2 \\
\hline $\begin{array}{l}\text { - Total lemak } \\
\text { - Asam linoleat }\end{array}$ & $\begin{array}{l}\mathrm{g} / 100 \mathrm{kkal} \\
\mathrm{mg} / 100 \mathrm{kkal}\end{array}$ & $\begin{array}{l}4.4 \\
300\end{array}$ & $\begin{array}{c}6.0 \\
-\end{array}$ & $\begin{array}{l}4.4 \\
300\end{array}$ & $\begin{array}{l}6 \\
-\end{array}$ & $\begin{array}{l}3.3 \\
300\end{array}$ & $\begin{array}{c}6 \\
\text { NS }\end{array}$ & - & $\begin{array}{c}5 \\
580\end{array}$ \\
\hline $\begin{array}{l}\text { - Asam } \alpha- \\
\text { linolenat }\end{array}$ & $\mathrm{mg} / 100 \mathrm{kkal}$ & 50 & NS & 50 & NS & - & - & - & 78 \\
\hline $\begin{array}{l}\text { Karbohidrat } \\
\text { Vitamin }\end{array}$ & g/100 kkal & 9.0 & 14.0 & 9.0 & 14 & - & - & - & 11 \\
\hline -Vitamin A & $\underset{\text { kkal }}{\mu \mathrm{g}} \mathrm{RE} / 100$ & 60 & 180 & 60 & 180 & 75 & 150 & 55.8 & 87.3 \\
\hline -Vitamin D & $\mu \mathrm{g} / 100 \mathrm{kkal}$ & 1 & 2.5 & 1 & 2.5 & 1 & 2 & 0.8 & 1.7 \\
\hline -Vitamin E & $\begin{array}{l}\mathrm{mg} \\
\mathrm{TE} / 100 \mathrm{kkal}\end{array}$ & 0.5 & - & 0.5 & - & 0.7 & NS & 0.4 & 1.4 \\
\hline -Vitamin K & $\mu \mathrm{g} / 100 \mathrm{kkal}$ & 4 & - & 4 & - & 4 & NS & 0.9 & 5.8 \\
\hline -Tiamin & $\mu \mathrm{g} / 100 \mathrm{kkal}$ & 60 & - & 60 & - & 40 & NS & 29.8 & 80 \\
\hline -Riboflavin & $\mu \mathrm{g} / 100 \mathrm{kkal}$ & 80 & - & 80 & - & 60 & NS & 44.6 & 140 \\
\hline -Niasin & $\mu \mathrm{g} / 100 \mathrm{kkal}$ & 300 & - & 300 & - & 250 & NS & 223.2 & 820 \\
\hline -Piridoksin & $\mu \mathrm{g} / 100 \mathrm{kkal}$ & 35 & - & 35 & - & 35 & NS & 14.9 & 60 \\
\hline -Vitamin $\mathrm{B}_{12}$ & $\mu \mathrm{g} / 100 \mathrm{kkal}$ & 0.1 & - & 0.1 & - & 0.15 & NS & 0.04 & 0.29 \\
\hline $\begin{array}{l}\text {-Asam } \\
\text { pantotenat }\end{array}$ & $\mu \mathrm{g} / 100$ kkal & 400 & - & 400 & - & 300 & NS & - & 780 \\
\hline -Asam folat & $\mu \mathrm{g} / 100$ kkal & 10 & - & 10 & - & 4 & NS & 9.7 & 19 \\
\hline -Vitamin C & mg/100 kkal & 10 & - & 10 & - & 8 & NS & 4.5 & 16 \\
\hline $\begin{array}{l}\text {-Biotin } \\
\text { Mineral }\end{array}$ & $\mu \mathrm{g} / 100 \mathrm{kkal}$ & 1.5 & - & 1.5 & - & 1.5 & - & - & 1.9 \\
\hline -Besi & $\mathrm{mg} / 100 \mathrm{kkal}$ & 0.45 & - & 0.45 & - & 0.15 & NS & 0.06 & 1.2 \\
\hline $\begin{array}{l}\text {-Kalsium } \\
\text {-Fosfor }\end{array}$ & $\begin{array}{l}\mathrm{mg} / 100 \mathrm{kkal} \\
\mathrm{mg} / 100 \mathrm{kkal}\end{array}$ & $\begin{array}{l}50 \\
25\end{array}$ & - & $\begin{array}{l}50 \\
25\end{array}$ & - & $\begin{array}{l}50 \\
25\end{array}$ & $\begin{array}{l}\text { NS } \\
\text { NS }\end{array}$ & $\begin{array}{l}29.8 \\
13.4\end{array}$ & $\begin{array}{l}74 \\
41\end{array}$ \\
\hline -Magnesium & $\mathrm{mg} / 100 \mathrm{kkal}$ & 5 & - & 5 & - & - & - & 3.9 & 8.7 \\
\hline -Natrium & mg/100 kkal & 20 & 60 & 20 & 60 & 20 & 60 & - & 30 \\
\hline -Klorida & mg/100 kkal & 50 & 160 & 50 & 160 & - & - & - & 64 \\
\hline -Kalium & mg/100 kkal & 60 & 180 & 60 & 180 & 80 & 200 & - & 105 \\
\hline -Mangan & $\mu \mathrm{g} / 100$ kkal & 1 & - & 1 & - & - & - & 0.4 & 9.7 \\
\hline -lodium & $\mu \mathrm{g} / 100 \mathrm{kkal}$ & 10 & - & 10 & - & - & - & 13 & 13 \\
\hline -Selenium & $\mu \mathrm{g} / 100 \mathrm{kkal}$ & 1 & - & 1 & - & - & - & 0.9 & 1.4 \\
\hline -Tembaga & $\mu \mathrm{g} / 100 \mathrm{kkal}$ & 35 & - & 35 & - & - & - & - & 62 \\
\hline $\begin{array}{l}\text {-Seng } \\
\text { Komponen } \\
\text { lain }\end{array}$ & $\mathrm{mg} / 100 \mathrm{kkal}$ & 0.5 & - & 0.5 & - & 0.5 & 1.5 & 0.2 & 0.64 \\
\hline -Kolin & $\mathrm{mg} / 100 \mathrm{kkal}$ & 7 & - & 7 & - & 7 & NS & - & 16 \\
\hline -Myo-Inositol & $\mathrm{mg} / 100 \mathrm{kkal}$ & 4 & - & 4 & - & - & - & - & 9.7 \\
\hline -L-Karnitin & $\mathrm{mg} / 100 \mathrm{kkal}$ & 1.2 & NS & 1.2 & NS & - & - & - & 1.9 \\
\hline
\end{tabular}

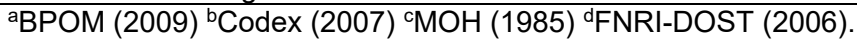

Nilai spesifikasi produk untuk jenis mikroba ALT (angka lempeng total) masih sesuai standar parameter $\mathrm{n}, \mathrm{c}, \mathrm{m}$ dan $\mathrm{M}$. Berdasarkan regulasi Indonesia, Internasional, Malaysia dan Filipina mensyaratkan nilai parameter $\mathrm{n}, \mathrm{c}, \mathrm{m}, \mathrm{M}$ secara berturut-turut adalah 5, 2, $5 \times 10^{2}$ dan $5 \times 10^{3}$. Nilai ALT merupakan indikator kondisi sanitasi proses dan lingkungan. Regulasi Internasional tidak menstandarkan nilai ALT melainkan nilai bakteri aerob mesofilik sebagai indikator cara produksi infant formula yang baik. 
Tabel 3 perbandingan regulasi terkait keamanan mikrobiologi susu infant formula.

\begin{tabular}{|c|c|c|c|c|c|c|c|}
\hline \multirow[t]{2}{*}{ Jenis Mikroba } & Satuan & Parameter & $\begin{array}{l}\text { Regulasi } \\
\text { Indonesia }^{a}\end{array}$ & $\begin{array}{c}\text { Regulasi } \\
\text { Internasional }\end{array}$ & $\begin{array}{l}\text { Regulasi } \\
\text { Malaysia }^{c}\end{array}$ & $\begin{array}{l}\text { Regulasi } \\
\text { Filipina }^{d}\end{array}$ & $\begin{array}{l}\text { Spesifikasi } \\
\text { Produk }\end{array}$ \\
\hline & & \multicolumn{6}{|c|}{ Batas Maksimum } \\
\hline \multirow[t]{4}{*}{ ALT } & koloni & $n$ & 5 & 5 & $10^{4}$ & 5 & 5 \\
\hline & $\lg$ & c & 2 & 2 & & 2 & 2 \\
\hline & & $\mathrm{m}$ & $5 \times 10^{2}$ & $5 \times 10^{2}$ & & $5 \times 10^{2}$ & $5 \times 10^{2}$ \\
\hline & & M & $5 \times 10^{3}$ & $5 \times 10^{3}$ & & $5 \times 10^{3}$ & $5 \times 10^{3}$ \\
\hline \multirow{4}{*}{$\begin{array}{l}\text { Enterobacteri } \\
\text { ceae }\end{array}$} & $/ 10 \mathrm{~g}$ & $\mathrm{n}$ & 10 & - & - & 10 & 10 \\
\hline & & c & 2 & & & 2 & 2 \\
\hline & & $\mathrm{m}$ & 0 & & & 0 & 0 \\
\hline & & $\mathrm{M}$ & NA & & & NA & NA \\
\hline \multirow{4}{*}{$\begin{array}{l}\text { E.sakazakii / } \\
\text { Cronobacter } \\
\text { spp }\end{array}$} & $/ 10 \mathrm{~g}$ & $\mathrm{n}$ & 30 & 30 & - & 30 & 30 \\
\hline & & $\mathrm{c}$ & 0 & 0 & & 0 & 0 \\
\hline & & $\mathrm{m}$ & Negatif & Negatif & & 0 & Negatif \\
\hline & & $\mathrm{M}$ & NA & - & & - & NA \\
\hline \multirow[t]{4}{*}{ Salmonella } & $125 \mathrm{~g}$ & $\mathrm{n}$ & 30 & 60 & - & 60 & 30 \\
\hline & & $\mathrm{C}$ & 0 & 0 & & 0 & 0 \\
\hline & & $\mathrm{m}$ & Negatif & Negatif & & 0 & Negatif \\
\hline & & $M$ & NA & - & & - & NA \\
\hline \multirow[t]{4}{*}{ Coliform } & koloni & $\mathrm{n}$ & - & - & 10 & 5 & Negatif \\
\hline & $\lg$ & c & & & & 2 & \\
\hline & & $\mathrm{m}$ & & & & 3 & \\
\hline & & $M$ & & & & 11 & \\
\hline \multirow[t]{4}{*}{ E. coli } & MPN/ & $\mathrm{n}$ & - & - & - & 10 & - \\
\hline & $\mathrm{g}$ & $\mathrm{C}$ & & & & 1 & \\
\hline & & $\mathrm{m}$ & & & & 1.8 & \\
\hline & & $M$ & & & & 10 & \\
\hline
\end{tabular}

aBPOM (2016) ${ }^{b}$ Codex (2008) ${ }^{\mathrm{c}} \mathrm{MOH}(1985){ }^{\mathrm{d} D O H}-F D A(2013)$.

Perbandingan regulasi terkait keamanan kimia pada susu Infant Formula dapat dilihat pada Tabel 4. Spesifikasi parameter susu terkait keamanan kimia sudah memenuhi syarat mandatori regulasi sebesar $71.42 \%$ (5/7). Jenis kimia pada spesifikasi produk yang belum memenuhi syarat mandatori adalah parameter Aflatoksin M1 dan melamin. Nilai spesifikasi produk untuk parameter aflatoksin M1 sudah sesuai regulasi Internasional sebesar $0.5 \mu \mathrm{g} / \mathrm{kg}$ namun belum memenuhi regulasi Malaysia sebesar 0.025 $\mu \mathrm{g} / \mathrm{kg}$. Hal ini dikarenakan komoditi infant formula pada regulasi Internasional mengacu pada komoditi susu, sedangkan pada regulasi Malaysia komoditi tercantum secara khusus dengan nilai standar lebih kecil.

Nilai spesifikasi produk untuk jenis kimia Arsen masih sesuai standar regulasi. Regulasi Indonesia dan Malaysia mensyaratkan batas arsen pada susu infant formula tidak boleh lebih dari $0.02 \mathrm{mg} / \mathrm{kg}$ produk siap konsumsi. Menurut Anggraini (2009), berbagai studi menunjukkan bahwa jumlah arsen dalam asupan sangat kecil dapat memberikan efek menguntungkan bagi kesehatan. Hal ini yang menyebabkan regulasi Internasional tidak mensyaratkan jenis cemaran kimia arsen.

Tabel 4 Perbandingan regulasi terkait keamanan kimia susu infant formula.

\begin{tabular}{|c|c|c|c|c|c|}
\hline Jenis Kimia & Satuan & $\begin{array}{c}\text { Regulasi } \\
\text { Indonesia }^{\text {a }}\end{array}$ & $\begin{array}{c}\text { Regulasi } \\
\text { Internasional }^{b}\end{array}$ & $\begin{array}{l}\text { Regulasi } \\
\text { Malaysia }^{c}\end{array}$ & $\begin{array}{c}\text { Spesifikasi } \\
\text { produk }\end{array}$ \\
\hline Arsen (As) & $\mathrm{mg} / \mathrm{kg}$ & 0.02 & - & 0.1 & 0.02 \\
\hline Timbal (Pb) & $\mathrm{mg} / \mathrm{kg}$ & 0.01 & 0.01 & 0.02 & 0.01 \\
\hline Merkuri (Hg) & $\mathrm{mg} / \mathrm{kg}$ & 0.01 & - & 0.05 & 0.01 \\
\hline Kadmium (Cd) & $\mathrm{mg} / \mathrm{kg}$ & 0.01 & - & 1 & 0.008 \\
\hline Timah (Sn) & $\mathrm{mg} / \mathrm{kg}$ & 10 & - & 50 & 10 \\
\hline Aflatoxin M1 & $\mu \mathrm{g} / \mathrm{kg}$ & - & 0.5 & 0.025 & 0.5 \\
\hline Melamin & $\mathrm{mg} / \mathrm{kg}$ & - & 1 & - & - \\
\hline
\end{tabular}

${ }^{a}$ BPOM (2017) ${ }^{b}$ Codex (2009) ${ }^{\mathrm{c} M O H}(1985)$

\subsection{Regulasi terkait kemasan susu infant formula}

Regulasi terkait kemasan susu Infant Formula dapat dilihat pada Tabel 5 . Spesifikasi parameter susu terkait kemasan sudah memenuhi syarat mandatori regulasi sebesar 92.31\% (11/12). Menurut regulasi Malaysia, pernyataan mengenai produk alergen pada kemasan merupakan parameter mandatori yang tidak ditampilkan pada kemasan produk. 
Tabel 5 Perbandingan regulasi terkait kemasan susu infant formula.

\begin{tabular}{|c|c|c|c|c|c|}
\hline Parameter & $\begin{array}{l}\text { Regulasi } \\
\text { Indonesi } \\
a^{a}\end{array}$ & $\begin{array}{l}\text { Regulasi } \\
\text { CODEX }^{b}\end{array}$ & $\begin{array}{l}\text { Regulasi } \\
\text { Malaysia }^{c}\end{array}$ & $\begin{array}{l}\text { Regulasi } \\
\text { Filipinad }^{d}\end{array}$ & $\begin{array}{c}\text { Spesifikasi } \\
\text { Kemasan }\end{array}$ \\
\hline Nama produk & $\sqrt{ }$ & $\sqrt{ }$ & $\sqrt{ }$ & $\sqrt{ }$ & $\sqrt{ }$ \\
\hline Nama merek & - & - & - & $\sqrt{ }$ & $\sqrt{ }$ \\
\hline Daftar bahan yang digunakan & $\sqrt{ }$ & $\sqrt{ }$ & $\sqrt{ }$ & $\sqrt{ }$ & $\sqrt{ }$ \\
\hline Berat bersih atau isi bersih & $\sqrt{ }$ & $\sqrt{ }$ & $\sqrt{ }$ & $\sqrt{ }$ & $\sqrt{ }$ \\
\hline Informasi nilai gizi & $\sqrt{ }$ & - & $\sqrt{ }$ & $\sqrt{ }$ & $\sqrt{ }$ \\
\hline Tanggal kadaluwarsa & $\sqrt{ }$ & $\sqrt{ }$ & $\sqrt{ }$ & $\sqrt{ }$ & $\sqrt{ }$ \\
\hline Petunjuk penyimpanan & $\sqrt{ }$ & $\sqrt{ }$ & $\sqrt{ }$ & $\sqrt{ }$ & $\sqrt{ }$ \\
\hline Keterangan tentang peruntukan & $\sqrt{ }$ & - & - & - & $\sqrt{ }$ \\
\hline Cara penggunaan & $\sqrt{ }$ & $\sqrt{ }$ & - & $\sqrt{ }$ & $\sqrt{ }$ \\
\hline $\begin{array}{l}\text { Nama dan alamat pihak yang } \\
\text { memproduksi atau memasukkan } \\
\text { ke Negara bersangkutan }\end{array}$ & $\sqrt{ }$ & $\sqrt{ }$ & $\sqrt{ }$ & $\sqrt{ }$ & $\sqrt{ }$ \\
\hline Allergen & - & - & $\sqrt{ }$ & $\sqrt{ }$ & - \\
\hline Identifikasi lot & - & $\sqrt{ }$ & - & $\sqrt{ }$ & $\sqrt{ }$ \\
\hline
\end{tabular}

Sumber : aMenkes (2013) ${ }^{\mathrm{b}}$ Codex (2008) ${ }^{\mathrm{c}} \mathrm{MOH}(1985){ }^{\mathrm{d} D O H}-F D A(2014)$.

\subsection{Kondisi Aktual Laboratorium Susu Infant Formula dalam Pemenuhan Persyaratan ISO 17025 dan Rekomendasi Pemenuhan Persyaratan atas Kesenjangan yang Ditemukan}

Tabel 6 menunjukkan data kuantitaif pemenuhan seluruh komponen persyaratan ISO 17025 di laboratorium susu infant formula. Data tersebut menunjukkan bahwa laboratorium pengujian susu infant formula sudah mengimplementasikan $93 \%$ pemenuhan persyaratan teknis ISO 17025 . Pemenuhan persyaratan teknis terhadap masing-masing sub klausul keterlusuran metrologis, pemilihan, verifikasi dan validasi metode, pengambilan sampel dan penanganan barang yang diuj sudah mencapai $100 \%$, namun untuk subklausul peralatan hanya mencapai $78 \%$.

Hasil penilaian terhadap pemenuhan persyaratan ISO 17025 menunjukkan bahwa laboratorium sudah menerapkan 93\%. Laboratorium kini sedang mempersiapkan untuk mendapat akreditasi ISO 17025 versi 2017 dan mampu melaksanakan pengujian sesuai persyaratan teknis. Menurut Hadi (2018), kajian penerbitan edisi ketiga ISO 17025 : 2017 dimulai pada Februari 2015 sebagai hasil dari proposal bersama ILAC dan South African Bureau of Standards (SABS) yang merupakan anggota ISO dan tuan rumah Komite Nasional untuk Internasional Electrotechnical Commision (IEC).

Hasil analisis terhadap pemenuhan persyaratan ISO 17025 : 2017 terkhusus untuk parameter mutu (karbohidrat dan vitamin B3) dan keamanan (angka lempeng total dan arsen) di Laboratorium susu infant formula terdapat beberapa kesenjangan.
1.

Kesenjangan terhadap persyaratan peralatan

Hasil penilaian terhadap pemenuhan persyaratan peralatan di laboratorium susu infant formula mencapai nilai $78 \%$ dengan skala 3. Persyaratan kriteria commissioning peralatan sudah terpenuhi namun tidak dilakukan secara konsisten. Adapun kriteria yang tidak terpenuhi pada peralatan laboratorium yaitu laporan kalibrasi yang tidak dijalankan secara konsisten yaitu pada alat oven, HPLC dan waterbath. Laporan kalibrasi oven tidak tersedia (alat baru). Laporan kalibrasi HPLC terakhir jatuh pada tanggal 8 Februari 2017. Laporan kalibrasi waterbath terakhir jatuh pada tahun 2016. Peralatan laboratorium yang kinerjanya tidak memenuhi persyaratan teknis selain dapat mempengaruhi mutu data hasil pengujian juga akan menimbulkan biaya kegagalan.

Peralatan yang belum memenuhi syarat kalibrasi juga mempengaruhi kriteria penanganan peralatan. Hal ini juga ditemukan dalam penelitian yang dikaji oleh Cebekhulu dan Mugova (2017) yaitu tidak ditemukan rekaman peralatan laboratorium. Program pemeliharaan peralatan laboratorium telah terlaksana di laboratorium meliputi jadwal pemeliharaan, dilaksanakan oleh personel yang berkompeten serta tersedia rekaman pemeliharaan pencegahan, kerusakan, perbaikan dan modifikasi. Untuk menjaga kinerja instrumentasi yang sensitif, laboratorium sudah mengendalikan kondisi akomodasi dan lingkungan khususnya suhu dan kelembapan, suhu ruangan dipelihara pada suhu $20^{\circ} \mathrm{C} \pm 5^{\circ} \mathrm{C}$ dan kelembapan udara relative berkisar $55 \%$ $\mathrm{RH} \pm 10 \% \mathrm{RH}$. 
Tabel 6 Pemenuhan persyaratan iso 17025 di laboratorium susu infant formula.

\begin{tabular}{|c|c|c|c|c|c|c|}
\hline $\begin{array}{c}\text { Persyaratan } \\
\text { (tambah } \\
\text { kolom untuk } \\
\text { rincian } \\
\text { karakteristik) } \\
\end{array}$ & Parameter & $\begin{array}{l}\text { Jumlah } \\
\text { parameter } \\
\text { (x) }\end{array}$ & $\begin{array}{c}\text { Nilai } \\
\text { Penuh } \\
(3 x)\end{array}$ & $\begin{array}{l}\text { Nilai } \\
\text { Aktual } \\
\text { (y) }\end{array}$ & $\begin{array}{c}\% \text { Pemenuhan } \\
\text { terhadap nilai } \\
\text { penuh }(y / 3 \times x \\
100 \%)\end{array}$ & $\begin{array}{l}\% \text { Pemenuhan } \\
\text { terhadap total } \\
\text { nilai penuh (y/z } \\
\quad \times 100 \%)\end{array}$ \\
\hline Peralatan & $\begin{array}{ll}\text { - } & \text { Commisioning } \\
\text { - } & \text { Penanganan } \\
\text { - } & \text { Pemeliharaan } \\
\text { - } & \text { Program kalibrasi } \\
\text { - } & \text { Pengecekan antara } \\
\text { - } & \text { Rekaman }\end{array}$ & 6 & 18 & 14 & $78 \%$ & $26 \%$ \\
\hline $\begin{array}{l}\text { Kemampuan } \\
\text { telusur }\end{array}$ & $\begin{array}{ll}\text { - } & \text { Acuan kalibrasi } \\
\text { - } & \text { Ketidakpastian } \\
& \text { pengukuran } \\
\text { - } & \text { Pemeliharaan } \\
& \text { rekaman } \\
\text { - } & \text { Kompetensi analis } \\
- & \text { Acuan sistem } \\
& \text { satuan internasional }\end{array}$ & 5 & 15 & 15 & $100 \%$ & $28 \%$ \\
\hline $\begin{array}{l}\text { Pemilihan, } \\
\text { metode } \\
\text { verifikasi dan } \\
\text { validasi }\end{array}$ & $\begin{array}{ll}- & \text { Kesesuaian metode } \\
- & \text { Validasi/ verifikasi } \\
- & \text { Pemeliharaan } \\
\text { - } & \text { metode } \\
\text { Kompetensi personil }\end{array}$ & 4 & 12 & 12 & $100 \%$ & $22 \%$ \\
\hline $\begin{array}{l}\text { Pengambilan } \\
\text { Sampel }\end{array}$ & $\begin{array}{l}\text { Responsibility } \\
\text { laboratorium }\end{array}$ & 1 & 3 & 3 & $100 \%$ & $6 \%$ \\
\hline $\begin{array}{l}\text { Penanganan } \\
\text { barang yang } \\
\text { diuji }\end{array}$ & $\begin{array}{ll}\text { - } & \text { Prosedur } \\
\text { - } & \text { pengelolaan. } \\
\end{array}$ & 2 & 6 & 6 & $100 \%$ & $11 \%$ \\
\hline Jumlah & & 18 & $54(z)$ & & & $93 \%$ \\
\hline
\end{tabular}

Program kalibrasi peralatan telah terlaksana pada laboratorium dengan mempertimbangkan kapasitas dan resolusi peralatan, rentang kerja penggunaan, waktu kalibrasi. Program kalibrasi harus ditetapkan pada peralatan yang mempunyai pengaruh signifikan pada hasil pengujian. Peralatan yang telah dikalibrasi diberi identitas dan dilaporkan setiap minggu untuk memudahkan identifikasi status kalibrasi, tanggal kalibrasi dan pihak yang melakukan kalibrasi.

Pengecekan antara pada peralatan sudah terpenuhi dalam batas memadai namun tidak memberikan pengaruh langsung terhadap keamanan pangan karena belum ada program pengecekan yang dilakukan secara berkala. Semua peralatan yang mempengaruhi mutu data hasil pengujian diperlukan pengecekan antara untuk memelihara keyakinan pada status kalibrasi. Evaluasi hasil pengecekan antara dinyatakan dalam keadaan baik jika hasil berada dalam batas keberterimaan yang ditetapkan atau hasil perbandingan dengan peralatan yang telah dikalibrasi dinyatakan tidak beda nyata.

Rekaman peralatan sudah terpenuhi namun tidak dilakukan secara konsisten. Setiap peralatan yang memiliki signifikansi pada hasil pengujian harus dapat diidentifikasi secara unik. Adapun inventarisasi peralatan yang tersedia di laboratorium tersedia dalam bentuk formulir dan database dalam komputer. Dengan mengetahui status peralatan, hal-hal yang tidak diinginkan khususnya mengenai penggunaan peralatan serta mutu data dapat dihindari.

\section{Kesenjangan terhadap persyaratan kemampuan telusur \\ Hasil penilaian terhadap pemenuhan} persyaratan kemampuan telusur di laboratorium susu infant formula mencapai nilai $100 \%$ dengan skala 3. Acuan kalibrasi yang digunakan dilaboratorium sudah mengacu pada standar nasional atau internasional. Acuan kalibrasi menjadi penting karena suatu hasil pengukuran dengan tingkat akurasi yang tinggi dapat dijamin kebenarannya jika peralatan ukur yang telah digunakan telah dikalibrasi dan memiliki keterlusuran samapai ke sistem satuan internasional.

$$
\text { Metode evaluasi ketidakpastian }
$$
pengukuran dilakukan sesuai dengan metode yang telah disepakati dan dikalibrasi dengan standar acuan. Bukti kompetensi teknis telah disediakan oleh laboratorium saat melakukan satu atau lebih langkah dalam rantai keterlusuran. Satuan internasional yang digunakan untuk hasil analisa karbohidrat adalah $\%$ b/b. Satuan internasional yang digunakan untuk hasil analisa vitamin B3 adalah mg/100g. Satuan internasional yang digunakan untuk hasil analisa angka lempeng total adalah cfu/g. Satuan 
internasional yang digunakan untuk hasil analisa arsen adalah $\mathrm{ppm}(\mathrm{mg} / \mathrm{kg})$. Peralatan ukur yang dikendalikan harus dapat menjamin kebenaran hasil ketika digunakan dan tidak melebihi batas keberterimaan yang ditetapkan.

\section{Kesenjangan terhadap persyaratan} pemilihan, verifikasi dan validasi metode

Hasil penilaian terhadap pemenuhan persyaratan pemilihan, verifikasi dan validasi metode di laboratorium susu infant formula mencapai nilai $92 \%$ dengan skala 3. Validasi metode untuk analisa parameter karbohidrat matriks susu dilaksanakan pada Januari-Maret 2018. Validasi metode untuk analisa parameter vitamin B3 matriks susu dilaksanakan pada Januari 2016 Validasi metode untuk analisa parameter angka lempeng total matriks susu dilaksanakan pada Juni 2016 Validasi metode untuk analisa parameter arsen matriks susu dilaksanakan pada bulan Januari 2016 Idealnya laboratorium harus melakukan revalidasi secara berkala meskipun hanya meliputi aspek tertentu saja. Hal ini dimaksudkan agar laboratorium memiliki data validasi yang merupakan bukti objektif yang berlaku dilaboratorium dan sesuai dengan kebutuhannya.

\section{Kesenjangan terhadap persyaratan pengambilan sampel}

Hasil penilaian terhadap pemenuhan persyaratan pengambilan sampel di laboratorium susu infant formula mencapai nilai $100 \%$ dengan skala 3 . Laboratorium merupakan suatu organisasi yang berbeda dengan pelanggan. Sampel yang diterima oleh laboratorium dalam keadaan tertutup dan tidak diketahui nama sampel sehingga tidak bisa merubah atau mengganti isi sampel. Pemberian kode sampel ditempel pada setiap sampel sebagai identitas bagi pelanggan dan laboratorium. Analisis kesenjangan pengambilan sampel tidak dapat dilakukan di laboratorium karena dari mulai perencanaan, persiapan, prosedur hingga jaminan mutu dan pengendalian mutu pengambilan sampel dilakukan oleh pelanggan tanpa diketahui oleh personel laboratorium.

\section{Kesenjangan terhadap persyaratan penanganan barang yang diuji}

Hasil penilaian terhadap pemenuhan penanganan barang yang diuji di laboratorium susu infant formula mencapai nilai $100 \%$ dengan skala 3. Hasil ini menandakan Laboratorium bertanggung jawab penuh untuk memastikan adanya perlindungan atas kerahasiaan informasi dan hak kepemilikan pelanggan termasuk penyimpanan selama sampel di laboratorium dan penyampaian laporan hasil pengujian. Didalam menunjang hal tersebut, laboratorium mempunyai prosedur pengelolaan dan pemeliharaan sampel yang akan diuji sehingga dapat melindungi keutuhannya. Prosedur yang dimiliki oleh laboratorium meliputi proses penerimaan, identifikasi, penanganan, perlindungan, penyimpanan, waktu penyimpanan dan pemusnahan sisa sampel.

Kriteria pemeriksaan sampel oleh petugas penerima sampel meliputi identitas sampel, form permintaan analisa, kondisi sampel, wadah atau kemasan sampel, ukuran sampel dan jumlah sampel pengujian. Identitas sampel telah ditentukan oleh pelanggan secara sistem, sehingga petugas laboratorium hanya melakukan pengecekan identitas dengan form permintaan analisa yang dilampirkan oleh pelanggan. Rangkaian pengamanan sampel pengujian menggunakan program perangkat lunak sehingga setiap proses pengamanan sampel dapat dilakukan secara komputerisasi dari awal penerimaan sampel hingga pelaporan hasil analisa.

\section{Rekomendasi Pemenuhan Persyaratan ISO 17025}

Hasil analisis kesenjangan menunjukan laboratorium susu infant formula sudah memenuhi $93 \%$ dari semua persyaratan teknis ISO 17025. Salah satu cara untuk menentukan langkah dan urutan dalam pemenuhan persyaratan adalah dilakukan diskusi antar personel laboratorium (focus group discussion) dalam menanggulangi kesenjangan persyaratan ISO 17025 (Zamrudi dkk 2014). Aspek yang harus diperhatikan dalam pemenuhan persyaratan teknis adalah metode validasi, manajemen peralatan, kontrol kualitas dan keterlusuran (Zapata Liaurado dan Rauret 2007). Berdasarkan penelitian Cebekhulu dan Mugova (2017), rekomendasi persyaratan teknis pada laboratorium yaitu menjaga kondisi fasilitas dan peralatan laboratorium dengan baik. Adapun rekomendasi diberikan dengan mempertimbangkan hasil penilaian dan analisis kesenjangan yang ditemukan di laboratorium terhadap persyaratan ISO 17025 adalah sebagai berikut :

1. Kalibrasi peralatan

Kalibrasi peralatan secara berkala perlu dilakukan sesuai jadwal yang telah direncanakan. Untuk menjamin ini, petugas kontrol kalibrasi peralatan tidak dipegang oleh penyelia, tetapi ditugaskan pada satu personel khusus agar lebih fokus terhadap tugas dan tanggung jawabnya. 


\section{Penulisan logbook}

Logbook persyaratan penggunaan peralatan harus disediakan untuk mencapai kinerja alat yang baik dan benar. Personel yang mengoperasikan alat harus mengikuti instruksi kerja dan mengisi logbook persyaratan penggunaan peralatan. Apabila ada peralatan yang tidak memenuhi persyaratan teknis, personil harus mencatat kondisi tersebut pada logbook serta memberi label pada alat. Alat tidak digunakan selama masa perbaikan.

\section{Jadwal pengecekan antara}

Jadwal pengecekan antara sesuai dengan rekomendasi manufaktur pembuat peralatan. Kondisi pengecekan antara dilakukan pada peralatan dalam kondisi akan digunakan untuk melaksanakan pengujian, mengalami pembebanan berlebih, memberikan hasil yang mencurigakan, mengalami cacat atau penyimpangan dan berada diluar batas yang ditentukan. Apabila hasil pengecekan antara dinyatakan tidak memenuhi batas keberterimaan, maka pengecekan dapat diulang atau instrumen yang bersangkutan diperbaiki atau dikalibrasi.

\section{Rekaman peralatan}

Rekaman selama pemakaian alat mencakup identitas peralatan dan peranti lunak yang terpasang, nama manufaktur, identifikasi, tipe dan nomor seri, bukti verifikasi, lokasi, rencana pemeliharaan dan rincian penyimpangan alat. Setiap peralatan memiliki signifikansi pada hasil pegujian sehingga rekaman harus memudahkan untuk mengidentifikasi secara detail.

5. $\frac{\text { Perencanaan dan pelaksanaan }}{\underline{\text { validasi/verifikasi }}}$

Perencanaan dan pelaksanaan validasi/verifikasi metode dilakukan secara berkala. Rentang dan akurasi nilai yang diperoleh dari metode pengujian yang divalidasi harus relevan dengan kebutuhan pelanggan dan konsisten dengan persyaratan yang ditentukan. Persyaratan yang ditentukan menurut Khodabocus dan Balgolbin (2011) meliputi ketidakpastian pengukuran hasil, batas deteksi, batas kuantifikasi, batas linieritas, selektivitas metode, sensitivitas instrument batas repeatability dan ketahanan terhadap pengaruh eksternal.

Menurut Zapata Liaurado dan Rauret (2007), sistem audit harus dilakukan secara berkala untuk mengevaluasi hasil rekomendasi berlangsung secara berkelanjutan. Survei kepuasan pelanggan adalah salah satu cara untuk mengevaluasi keseluruhan kinerja dan mengidentifikasi peluang untuk perbaikan laboratorium.

\section{KESIMPULAN}

Regulasi susu infant formula belum diterapkan secara efektif pada laboratorium pengujian susu infant formula. Regulasi terkait keamanan mikrobiologi, kimia dan kemasan produk merupakan regulasi yang belum terpenuhi. Prinsip-prinsip penetapan regulasi dalam perumusan dan pengenmbangan standar perlu diterapkan lebih efektif.

Laboratorium masih memiliki kesenjangan dalam pemenuhan persyaratan parameter uji ISO 17025. Data kuantitatif hasil penilaian menunjukkan bahwa laboratorium pengujian susu infant formula sudah mengimplementasikan $93 \%$ pemenuhan persyaratan teknis ISO 17025 . Laboratrium mampu melakukan uji sesuai dengan regulasi teknis yang berlaku dari segi metode, peralatan dan kompetensi personel.

Rekomendasi dalam pemenuhan kesenjangan persyaratan teknis ISO 17025 dapat menjadi acuan bagi laboratorium sejenis lainnya. Rekomendasi mencakup kalibrasi peralatan, penulisan logbook, jadwal pengecekan antara, rekaman peralatan dan perencanaan dan pelaksanaan validasi/verifikasi.

\section{UCAPAN TERIMAKASIH}

Ucapan terima kasih kami sampaikan kepada salah satu laboratorium susu infant formula sebagai tempat penelitian. Ucapan terima kasih juga kami sampaikan kepada pihak-pihak yang mendukung penelitian ini.

\section{DAFTAR PUSTAKA}

Anggraini I. (2009). Kajian Kesesuaian Mutu Produk-Produk Formula Bayi di Pasar Indonesia dengan Standar Nasional Indonesia dan Standar Codex Alimentarius [Thesis]. Institut Pertanian Bogor, Bogor.

Angulo FJ, Cahill SM, Wachsmuth IK, Costarrica ML, Embarek PKB. (2008). Powdered Infant Formula as a Source of Salmonella Infection in Infants. Clinical Infectious Diseases. 46 (2) : 268-273.

Badan Pengawas Obat dan Makanan. (2009). Peraturan Kepala BPOM RI Nomor HK.00.05.1.52.3920 tentang Pengawasan Formula Bayi untuk Keperluan Medis Khusus. Jakarta : Badan POM RI.

Badan Pengawas Obat dan Makanan. (2016). Peraturan Kepala BPOM RI Nomor 16 Tahun 2016 tentang Kriteria Mikrobiologi 
Kajian Persyaratan Teknis Laboratorium Pengujian di Industri Susu Terhadap Produk Infant Formula Sesuai ISO 17025:2017 (Dwining Putri Elfriede, Harsi D. Kusumaningrum, Hanifah Nuryani Lioe)

Dalam Pangan Olahan. Jakarta : Badan POM RI.

Badan Pengawas Obat dan Makanan. (2017). Peraturan Kepala BPOM RI Nomor Nomor 23 Tahun 2017 tentang Batas Maksimum Cemaran Logam Berat Dalam Pangan Olahan. Jakarta : Badan POM RI.

Cebekhulu BMB \& Mugova C. (2017). Quality Control in a University Laboratory: Evaluating the Gap between ISO/IEC17025 Requirements and the Thin Section Laboratory's Processes. Proceedings of the International Symposium on Industrial Engineering and Operations Management (IEOM) Bristol. Wits University (UK). hlm 614-625.

Codex Alimentarius Internasional Food Standards. (2007). CODEX STAN 721981. Standard For Infant Formula And Formulas For Special Medical Purposes Intended For Infants. Rome : CAC.

Codex Alimentarius Internasional Food Standards. (2008). CAC/RCP 66-2008. Code Of Hygienic Practice For Powdered Formula For Infants And Young Children. Rome : CAC.

Codex Alimentarius Internasional Food Standards. (2009). CXS 193-1995. General Standard For Contaminants And Toxins In Food And Feed. Rome : CAC.

Dina, Wastra AR. (2013). Efektifitas Penerapan Sistem Manajemen Mutu SNI ISO/IEC 17025 : 2008 Di Laboratorium Benih. Jurnal Agribisnis. 7 (2) : 157-172.

Department of Health Food and Drug Administration Philipines. 2013. Revised Guidelines forThe Assessment of Microbiologycal Quality of Processed Food. Philipines : DOH-FDA.

Department of Health Food and Drug Administration Philipines. (2014). Revised Rules and Regulations Governing The Labelling of Prepacked Food Products Futher Amending Cenrtain Provisions of Administrative Order No. 88-B s.1984 or the "Rules and Regulations Governing the Labelling of Prepacked Food Products Distributed in the Philippines," and For Other Purposes. Philipines : DOH-FDA.

Firdaus H. (2015). Sistem Manajemen Mutu Laboratorium ISO 17025 : Solusi Peningkatan Kinerja Laboratorium Pengujian dan Kalibrasi di Pemerintah Daerah. http://www.smtp.lipi.go.id/. 3 Desember 2017.

Food and Nutrition Research Institute, Department of Science and Technology.
(2006). Recommended Energy and Nutrient Intakes. Philippines : FNRI-DOST.

Grochau IH, Ferreira CA, Ferreira JZ, Caten CS. (2010). Implementation of A Quality Management System In University Test Laboratories: A Brief Review And New Proposals. Accreditation and Quality Assurance. 15 : 681-689. doi: 10.1007/s0079-010-0713-6

Hadi A. (2018). Persyaratan Umum Kompetensi Laboratorium Pengujian dan Laboratorium Kalibrasi ISO/IEC 17025:2017. Jakarta : Gramedia.

Hervert CJ, Alles AS, Martin $\mathrm{NH}$, Boor KJ, Wiedmann M. (2016). Evaluation of Different Methods To Detect Microbial Hygiene Indicators Relevant In The Dairy Industry. Journal Dairy Science. 99 (9) : 7033-7042. doi : 10.3168/jds.2016-11074.

International Standard Organization. (2017). General Requirements for The Competence of Testing and Calibration Laboratories

Jamilah. (2015). Peran Laboratorium Terakreditasi Dalam Pengembangan Mutu dan Keamanan Pangan. http://bbihp.kemenperin.go.id. [diunduh 6 Januari 2018.

Khodabocus F \& Balgobin K. (2011). Implementation and Practical Benefits of ISO 17025 in a Testing Laboratory. University of Mauritius Research Journal. $17: 27-60$

Martoyo PM, Hariyadi RD, Rahayu WP. (2014). Kajian Standar Cemaran Mikroba dalam Pangan di Indonesia. Jurnal Standarisasi. 16 (2) : 113-124

Mayasari I. (2009). Pengaruh penerapan ISO 17025:2005 pada pengelolaan laboratorium pengujian konstruksi dinas pekerjaan umum provinsi DKI Jakarta tehadap kepuasan pelanggan [Thesis]. Universitas Indonesia, Jakarta.

Menteri Kesehatan. (2013). Peraturan Menteri Kesehatan Republik Indonesia Nomor 39 tentang Susu Formula Bayi dan Produk Bayi Lainnya

Misgiyarta \& Bintang M. (2011). Kontaminan Enterobacter sakazakii Pada Susu Formula Bayi dan Pengendaliannya. Buletin Teknologi Pascapanen Pertanian. 7 (1) : 1-7

Minister of Health. (1985). Food Regulations. Malaysia : $\mathrm{MOH}$.

Oktari RT. (2015). Evaluasi PRP Untuk Perbaikan Implementasi Sistem 
Manajemen Keamanan Pangan FSSC 22000:2013 Di PT Dairy Indonesia [Thesis]. Institut Pertanian Bogor, Bogor.

Oonaka K, Furuhata K, Hara M, Fukuyana M. (2010). Powder Infant Formula Milk Contaminated with Enterobacter sakazakii. Japanese Journal of Infectious Diseases. $63: 103-107$

Pebrianti Y. (2016). Kajian Penyusunan Dokumen Sistem (Panduan, Prosedur dan Formulir) Guna Mendukung Manajemen Mutu Perpustakaan. Jurnal Pari. 2 : 78-89

Ratseou E \& Ramphal. (2014). The Impact of Laboratory Quality Assurance Standards on Laboratory Operational Performance. African Journal of Hospitally, Tourism and Leisure. 3(2) : 1-13

Rose GA \& Johnson TV. (2017). Laboratory Accreditation : Why This Quality Matter Matters. Journal of The American Society of Echocardiography. 30 (9) : 923-925

[SNI] Standar Nasional Indonesia. (2008). Persyaratan Umum Kompetensi Laboratorium Pengujian dan Laboratorium Kalibrasi
Stajdohar O. (2008). Education And Training Of Laboratory Staff As A Part Of Laboratory Competence. Accreditation and Quality Assurance. 13 (4-5): 267-270.

Tampubolon BD, Ayuningtyas U, Setyoko AT. (2015). Kesiapan Pemberlakuan Wajib SNI Susu Bubuk dan SNI Susu Kental Manis di Indonesia. Jurnal Standarisasi.17 (2) : 157166

Ulfiati R. (2016). Implementasi Sistem Manajemen Mutu untuk Menjamin Konsistensi Kualitas Produk. Jurnal Standarisasi. 18 (3) : 195-204

Viola SCV, Bianchi F, Croce E dan Ceretti E. (2016). Are Food Labels Effective As A Means Of Health Prevention ?. Journal of Public Health Research. 5 (768) : 140-142

Zamrudi J, Kusumaningrum HD, Nuraida L. (2014). Analisis Pemenuhan Persyaratan Food Safety System Certification 22000 di Industri Kemasan Pangan. Jurnal Mutu Pangan. 1(2) : 46-53

Zapata DG, Liaurado M, Rauret G. (2007). Experience of Implementing ISO 17025 For The Accreditation of A University Testing Laboratory. Accreditation and Quality Assurance. 15 : 681-689 